\title{
Naturally occurring radionuclides in mushrooms from uranium mining regions in Germany
}

\author{
K. Wichterey and S. Sawallisch \\ Federal Office for Radiation Protection, Koepenicker Allee 120-130, 10318 Berlin, Germany
}

\begin{abstract}
There is a heavy legacy of former uranium mining and milling in Germany. Thousands of relics, mainly waste rock piles with enhanced levels of radionuclides of the uranium/radium series are often situated near residential areas. During the last years extensive investigations were carried out within the framework of the project "Altlastenkataster" (Register of Contaminated Sites) to identify and assess mining relics and the environmental impact caused by them. The investigations included sampling and measurements of biota. Since many waste rock piles or their surroundings are afforested, mushrooms were sampled, where available. Although the consumption rates are low, authorities have to answer the question if this pathway remarkably can contribute to the radiation exposure caused by ingestion and if people could consume these mushrooms or not. Measuring results of mushrooms from the data bese of mining related environmental radioactivity are evaluated and typical ranges of the concentrations of naturally occurring radionuclides for mushrooms are given, compared with data from literature and assessed. Based on the measuring values possible doses from the consumption of mushrooms are calculated using standard assumptions and conclusions are drawn.
\end{abstract}

\section{INTRODUCTION}

In some regions of Germany, mining, which started already in the Middle Ages, has left its marks on the landscape with thousands of relics. During the last 50 years especially uranium mining and milling caused deposits of waste rock material, partly with significantly enhanced levels of radionuclides of the uranium/radium series. Often these piles are situated near residential areas and are therefore regarded as sources of additional radiation exposure to the population.

From 1991 to 1999 extensive investigations were implemented by the Federal Office for Radiation Protection (BfS) within the framework of the project "Registration, investigation and radiological assessment of mining residues (Register of contaminated sites)" on behalf of the Federal Ministry for the Environment, Nature Conservation and Nuclear Safety. Thousands of samples were taken and measurements were carried out to assess mining relics and their environmental impact and to identify possible sources of increased radiation exposure [1]. The ingestion pathway was investigated as well by measuring biota. Since many waste rock piles are already afforested and people were concerned whether it was dangerous or not to consume mushrooms collected at these sites, wild-growing edible mushrooms were sampled where available.

\section{MEASUREMENTS}

Altogether about 100 samples of mushrooms from different mining regions and locations were collected; mainly mushrooms growing on piles and some from meadows in their surroundings. Most of them belong to the boletus family (Boletus, Suillus, Xerocomos, Leccinum species) and some to the agaric family (Lepiota and Agaricus species) and puff-balls (Lycoperda species).

The samples were cleaned and the relevant radionuclides of the uranium/radium series were measured. ${ }^{238} \mathrm{U}$ was calculated from total uranium $\left(\mathbf{U}_{\mathrm{nat}}\right)$ measured by fluorimetry or by ICP-MS (mass 
spectrometry with inductive coupled plasma), ${ }^{226} \mathrm{Ra}$ by gammaspectrometry or emanometry, ${ }^{210} \mathrm{Po} /{ }^{210} \mathrm{~Pb}$ by alpha-/ betaspectrometry (of $\left.\mathrm{Bi}^{210}\right)$ [2].

For all mushroom samples the following concentration $(\mathrm{B} q / \mathrm{kg}$ wet weight - WW) for the mentioned radionuclides was found:

Table 1: Concentrations of radionuclides of the ${ }^{238} \mathrm{U}$-series in mushrooms from mining areas

\begin{tabular}{|c|c|c|c|c|}
\hline Radionuclide & $\begin{array}{c}\text { Minimum value } \\
(\mathrm{Bq} / \mathrm{kg} \mathrm{WW})\end{array}$ & $\begin{array}{c}\text { Maximum value } \\
(\mathrm{Bq} / \mathrm{kg} \mathrm{WW})\end{array}$ & $\begin{array}{c}\text { Median } \\
(\mathrm{Bq} / \mathrm{kg} \mathrm{WW})\end{array}$ & $\begin{array}{c}\text { Number of } \\
\text { Values }\end{array}$ \\
\hline${ }^{238} \mathrm{U}$ & 0.01 & 25.9 & 0.4 & 81 \\
\hline${ }^{226} \mathrm{Ra}$ & 0.03 & 51.2 & 0.9 & 60 \\
\hline${ }^{210} \mathrm{~Pb}$ & 0.06 & 28.9 & 0.6 & 73 \\
\hline${ }^{210} \mathrm{Po}$ & 0.10 & 64.0 & 3.4 & 74 \\
\hline
\end{tabular}

The measurements from all locations have a wide variability of the concentrations of naturally occurring radionuclides. All of them have a range of two to three orders of magnitude and, in particular, high ${ }^{210}$ Po-values (maximum, mean) are obvious. For a detailed evaluation the frequency distributions of the four relevant radionuclides in mushrooms from all locations in mining regions are shown in Figures $1-4$.
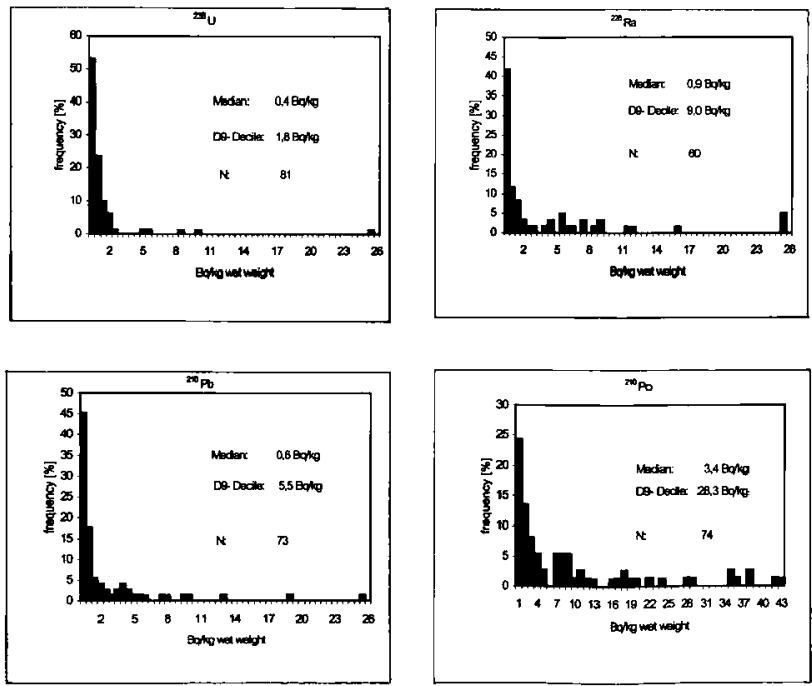

Figures 1-4: Frequency distributions of ${ }^{238} \mathrm{U},{ }^{226} \mathrm{Ra},{ }^{210} \mathrm{~Pb}$ and ${ }^{210} \mathrm{Po}$ in mushrooms

\footnotetext{
120 samples were not considered since their concentrations were below the detection limit of the method used.
} 
The frequency distribution of ${ }^{238} \mathrm{U}$ in Figure 1, which is a relatively unified picture, depicts that $90 \%$ of the values are below $1.5 \mathrm{~Bq} / \mathrm{kg} \mathrm{WW}$. The contamination of mushrooms with ${ }^{238} \mathrm{U}$ is low since it is no essential element for plant growth and the plant availability of uranium is low owing to its chemical properties.

For ${ }^{226} \mathrm{Ra}$ and ${ }^{210} \mathrm{~Pb}$ the frequency distributions differ from that of ${ }^{238} \mathrm{U}$ (Figures 2,3). The $90^{\text {th }}$ percentile are $9.0 \mathrm{~Bq} / \mathrm{kg} \mathrm{WW}$, respectively $5.5 \mathrm{~Bq} / \mathrm{kg} \mathrm{WW}$, e.g. there is a tendency of higher contamination with ${ }^{226} \mathrm{Ra}$ than with ${ }^{210} \mathrm{~Pb}$, which could be explained by higher mean specific activities of ${ }^{226} \mathrm{Ra}$ in the soil. The wide range in both frequency distributions may be due to large differences in plant availability caused by different soil properties and activities at the sampling sites.

The most diverse frequency distribution is given in Figure 4 for ${ }^{210} \mathrm{Po}$. The $90^{\text {th }}$ percentile is here at $28.3 \mathrm{~Bq} / \mathrm{kg}$ WW which is considerably higher than for the other radionuclides. The reason for this may be differences in soils of the sites and plant avajlability, and it may depend on the mushroom species as well. In any case there is an obviously higher concentration of ${ }^{210} \mathrm{Po}$ accumulated in mushrooms than of every other radionuclide of the ${ }^{238} \mathrm{U}$-series. There is no clear tendency between different species, but the highest ${ }^{210}$ Po-values occur in boletus like Leccinum sabrum, Leccinum aurantiacum, Suillus bovinus and Suillus grevillei, which form a symbiotic relationship with trees. In agaric species, which grow on humus or wood, no extraordinarily high ${ }^{210}$ Po concentration was detected. It seems, therefore, that there is a selective uptake availability of mushrooms, which is related to their special metabolism and protein contents. ${ }^{210} \mathrm{Po}$ is mostly bound in mushroom protein. It is assumed that ${ }^{210} \mathrm{Po}$ has an affinity to thiolgroups of the proteins $[3,4]$.

Like expected, the concentrations for all radionuclides of the ${ }^{238} \mathrm{U}$-series were higher in mushrooms only from piles compared to mushrooms from the mining regions altogether. Measurements are shown in Table 2.

Table 2: Concentrations of radionuclides of the ${ }^{238} \mathrm{U}$-series in mushrooms anly from piles

\begin{tabular}{|c|c|c|c|c|}
\hline Radionuclide & $\begin{array}{c}\text { Minimum value } \\
(\mathrm{Bq} / \mathrm{kg} \mathrm{WW})\end{array}$ & $\begin{array}{c}\text { Maximum value } \\
(\mathrm{Bq} / \mathrm{kg} \text { WW })\end{array}$ & $\begin{array}{c}\text { Median } \\
(\mathrm{Bq} / \mathrm{kg} \mathrm{WW})\end{array}$ & $\begin{array}{c}\text { Number of } \\
\text { values }\end{array}$ \\
\hline${ }^{238} \mathrm{U}$ & 0.01 & 25.9 & 0.5 & 46 \\
\hline${ }^{226} \mathrm{Ra}$ & 0.14 & 51.2 & 3.9 & 28 \\
\hline${ }^{210} \mathrm{~Pb}$ & 0.13 & 28.9 & 0.8 & 30 \\
\hline${ }^{210} \mathrm{Po}$ & 0.54 & 64.0 & 9.6 & 40 \\
\hline
\end{tabular}

Compared to that, the measured values of mushrooms from the unaffected surroundings of piles from copper ore mining and processing are clearly lower altogether, but there are maximum values for 210 Po as well (Table 3). These values are regarded as being representative for the background level of wild-growing mushrooms since only few data are available from literature for these radionuclides and they are not sufficient for a comprehensive survey $[5,6,7]$.

Table 3: Concentrations of radionuclides of the ${ }^{208} \mathrm{U}$-series in mushrooms from unaffected regions

\begin{tabular}{|c|c|c|c|c|}
\hline Radionuclide & $\begin{array}{c}\text { Minimum value } \\
(\mathrm{Bq} / \mathrm{kg} \mathrm{WW})\end{array}$ & $\begin{array}{c}\text { Maximum value } \\
(\mathrm{Bq} / \mathrm{kg} \mathrm{WW})\end{array}$ & $\begin{array}{c}\text { Median } \\
(\mathrm{Bg} / \mathrm{kg} \mathrm{WW})\end{array}$ & $\begin{array}{c}\text { Number of } \\
\text { values }\end{array}$ \\
\hline${ }^{238} \mathrm{U}$ & 0.009 & 0.35 & -0.15 & 11 \\
\hline${ }^{226} \mathrm{Ra}$ & 0.025 & 0.24 & 0.04 & 9 \\
\hline${ }^{210} \mathrm{~Pb}$ & 0.156 & 0.47 & 0.15 & 15 \\
\hline${ }^{210} \mathrm{Po}$ & 0.100 & 4.50 & 0.86 & 15 \\
\hline
\end{tabular}




\section{TRANSFER FROM SOIL SUBSTRATES}

The level of radioactivity in the fruiting body of mushrooms, of cause, depends on the concentrations of the soil substrate where the mycelia grows. Locally enhanced concentrations of the ${ }^{238} \mathrm{U}$-series in waste rock materials may explain higher values in mushrooms collected directly on piles. Samples of the corresponding upper soil layer (humus) with mycelia could not be taken of the sites where the mushrooms were found. The soil at the sites where mushrooms were found was taken from the layer from $0 \mathrm{~cm}$ to $30 \mathrm{~cm}$. It contains both, the upper organic layer as well as the underlying mineral soil or the weathered parent rock. Radioactivity can be taken up by the mycelia of mushrooms from these layers or it can be supplied subsequently. The concentrations in soil samples of piles in mining areas range from $50 \mathrm{~Bq} / \mathrm{kg}$ dry weight to $13,000 \mathrm{~Bq} / \mathrm{kg}$ with median values for ${ }^{238} \mathrm{U},{ }^{226} \mathrm{Ra}$ and ${ }^{210} \mathrm{~Pb}$ from $290 \mathrm{~Bq} / \mathrm{kg}$ to $325 \mathrm{~Bq} / \mathrm{kg}$. The measurements of soil were performed by gammaspectrometry and an equilibrium was assumed between ${ }^{210} \mathrm{~Pb}$ and ${ }^{210} \mathrm{Po}$ in soil samples. Therefore, ${ }^{210} \mathrm{Po}$ was measured in special cases only by means of alphaspectrometry.

The transfer of the concentrations from soil to mushrooms can roughly be described by the transfer factor or concentration ratio (CR), which is calculated as the quotient of the concentrations in mushrooms ( $\mathrm{Bq} / \mathrm{kg}$ wet weight) against the concentrations in soil $(\mathrm{Bq} / \mathrm{kg}$ dry weight). For the relevant radionuclides the following concentration ratios could be derived from the corresponding data pairs for mushrooms from piles:

$$
{ }^{238} \mathrm{U}-1.3 \mathrm{E}-03,{ }^{226} \mathrm{Ra}-1.3 \mathrm{E}-02,{ }^{210} \mathrm{~Pb}-4.8 \mathrm{E}-03,{ }^{210} \mathrm{Po}-4.9 \mathrm{E}-02
$$

The concentration ratios vary within one order of magnitude. For ${ }^{210}$ Po the calculation could be based on six value pairs only because of lacking ${ }^{210}$ Po-measurements in soil, but similar results were obtained when ${ }^{210} \mathrm{~Pb}$-values in soil were calculated against ${ }^{210} \mathrm{Po}$-values in mushrooms, assuming cquilibrium between ${ }^{210} \mathrm{~Pb}$ and ${ }^{210} \mathrm{Po}$ in soil samples.

The transfer of radionuclides from soil can be regarded as the only source of contamination since surface contamination from fallout can almost be excluded when mushrooms are usually collected as young specimens. An uptake of airborne ${ }^{210} \mathrm{Po}$ is not relevant since there are no enhanced ${ }^{210} \mathrm{~Pb}$ levels in mushrooms, which could be expected otherwise. The same is true for possibly adhering surface contamination from the soil substrate which was usually removed during sample preparation.

\section{ASSESSMENT OF THE RESULTING DOSES}

Although the consumption rates are low, authorities have to answer the question whether this pathway can remarkably contribute to the radiation exposure caused by ingestion and whether people can consume these mushrooms or not. The Commission on Radiological Protection in Germany recommended a reference level for the effective dose for members of the public of $1 \mathrm{mSv}$ per year as a result of mining activities, which has to be applied additionally to the background radiation exposure [8].

Therefore, an assessment of the annual effective dose due to mushroom consumption was carried out one for six age groups according to the Euratom-Directive. As recommended by the Federal Health Agency [9] a maximum consumption rate of $200 \mathrm{~g}-250 \mathrm{~g}$ wild-growing mushrooms per meal for adults was assumed at regular weekly consumption (10kg/a). Since conservation methods are necessary for reaching this amount a more realistic assumption $(5 \mathrm{~kg} / \mathrm{a})$ is made for the growing season only. Regarding the contamination in mushrooms minimum and maximum values $\left(90^{\text {th }}\right.$ percentile) were used. Table 4 shows the effective dose via ingestion of $5 \mathrm{~kg} / \mathrm{a}$ mushrooms from mining piles and from unaffected regions. 
Table 4: Efrective dose via ingestion of mushrooms from piles in uranium mining regions and in unaffected regions

\begin{tabular}{|c|c|c|c|}
\hline $\begin{array}{c}\text { Age group } \\
\text { (years) }\end{array}$ & $\begin{array}{c}\text { Consumption rate } \\
(\mathrm{kg} / \mathrm{a})\end{array}$ & \multicolumn{2}{|c|}{$\begin{array}{c}\text { Dose range } \\
\text { (mSv/a) }\end{array}$} \\
\hline & & Mushrooms from piles & Mushrooms in unaffected areas \\
\hline $2-7$ & 0.5 & $0.02-0.09$ & $0.002-0.007$ \\
\hline $7-12$ & 2.5 & $0.08-0.30$ & $0.007-0.021$ \\
\hline $12-17$ & 5 & $0.12-0.48$ & $0.010-0.028$ \\
\hline$>17$ & 5 & $0.07-0.26$ & $0.006-0.019$ \\
\hline
\end{tabular}

In spite of the small share of mushrooms in the total food consumption rates, in the case of mushrooms from piles for several age groups relatively high dose contributions can be calculated compared to the existing reference level of $1 \mathrm{mSv} / \mathrm{a}$. Therefore, the ingestion of mushrooms can be a relevant exposure pathway and should always be investigated to do exposure assessments in mining regions. This is recommended not only from the radiation protection point of view, but for toxicological reasons as well, since enhanced levels of heavy metals can be assumed in mushrooms from these sites, too [10]. It is rather unlikely, however, that the total yearly mushroom consumption is collected from piles exclusively. As compared to Table 4, column 4, illustrating the effective dose via ingestion of mushrooms from unaffected areas it can be concluded that the overwhelming part of the doses calculated in Table 4, column 3 originates from mining related radiation exposure. Even if most conservative assumptions for a weekly consumption of wild-growing mushrooms $(10 \mathrm{~kg} / \mathrm{a})$ and maximum values for the concentration would be used the effective dose via ingestion of mushrooms from unaffected sites contributes a negligible part to the total dose of the population. It represents the dose resulting from background radiation level and does not have to be considered.

Figure 5 illustrates the dose contributions of the single radionuclides to the dose for the critical group of young people (12-17 years).

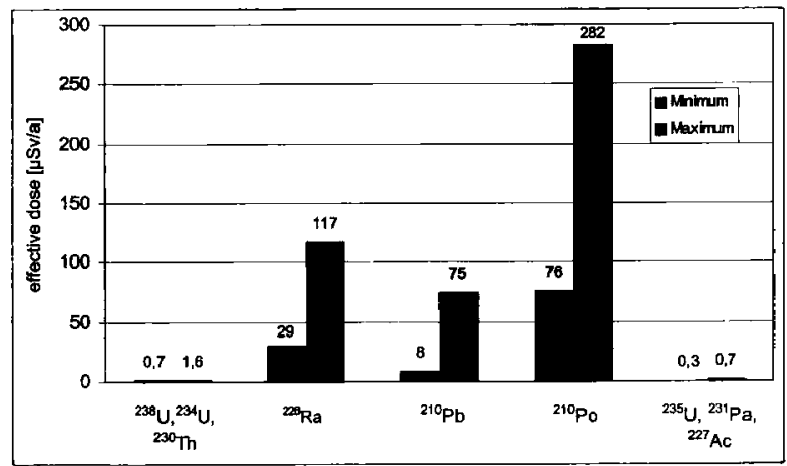

Figure 5: Contribution of radionuclides to the effective dose of the critical group

\footnotetext{
2 Age-groups 0-1y and 1-2y are not considered since no consumption is assumed.
} 
As can be seen about two thirds of the contribution to the effective dose via ingestion of wildgrowing mushrooms are due to ${ }^{210} \mathrm{Po}$, one fourth is due to ${ }^{226} \mathrm{Ra}$ and less than $10 \%$ to ${ }^{210} \mathrm{~Pb}$, whereas the contribution of uranium from both series is negligible. Therefore, more attention should be paid to measurements of ${ }^{210} \mathrm{Po}$ in mushrooms.

\section{References}

[1] Ettenhuber, E., Gehrcke, K.; Radiologische Erfassung, Untersuchung und Bewertung bergbaulicher Altlasten, BfS-SCHR-22/01, (2001)

[2] Bundesamt für Strahlenschutz, ST 2-01/1995 „Parallelbestimmung von natürlichen Radionukliden in Proben der Verdachtsfläche 18 im Rahmen des Projektes ,Radiologische Erfassung, Untersuchung und Bewertung bergbaulicher Altlasten (Altlastenkataster)" "s, Maßnahmen zur Qualitätsüberwachung, Teil IV, Berlin, Dezember 1995ST2-Bericht zur Q-Sicherung

[3] Lerch, K.; Copper Proteins with Dinuclear Active Sites. In: R.B. King, Encyclopedia of inorganic chemistry, 1994, pp. 850 - 869, Chichester: Wiley

[4] Kăgi, J.H.R., Schăffer, A.; Biochemistry of Metallothionein, Biochemistry, November 15, 1988 , Volume 27, Number 23, pp. 8509 - 8515

[5] Steinhäusler, F,; Long-term investigations in Austria of environmental natural sources of ionizing radiation and their impact on man, Habilitationsschrift der Paris-London-Universität in Salzburg 1980

[6] Eck1, P, Hofmann, W, Türck, R.; Uptake of natural and man-made radionuclides by lichens and mushrooms, Radiation and Environmental Biophysics, (1986) 25: 43-54

[7] Frindik, O., Inhalt von Thorium und Uran in Nahrungsmitteln sowic deren Zufuhr, In: A. Dahlheimer, M. Hartmann, K. König (Hrsg.), Körperaktivităt durch natürliche Quellen, BfS - ISH $-183 / 98: 32-41$

[8] BMU, Strahlenschutzgrundsätze für die Verwahrung, Nutzung oder Freigabe von kontaminierten Materialien, Gebäuden, Flächen oder Halden aus dem Uranerzbergbau, Veröffentlichungen der Strahlenschutzkommission, Stuttgart 1992

[9] Bundesgesundheitsblatt 21, 204, 207 (1978)

[10] Seeger, R., Toxische Schwermetalle in Pilzen, Deutsche Apotheker Zeitung, 122. Jahrg., Nr. 37 